\title{
THE PHENOLIC COMPOSITION AND THE ANTIOXIDANT CAPACITY OF SERBIAN RED WINES
}

Milan N. Mitić*, Danijela A. Kostić, Aleksandra N. Pavlović,

Faculty of Sciences and Mathematics, Department of Chemistry, University of Niš, Niš, Serbia

(ORIGINAL SCIENTIFIC PAPER)

UDC 663.21:543.42

The aim of this study was to determine the phenolic composition and free radical scavenging activityof some Serbian commercially red wines by using DPPH assays. The wines of red grape varieties and different vintage were analysed in June 2012. Standard spectrophotometric methods of the analysis for general wine components were used for the preliminary control of the selected wines. Anthocyanins in the wine were measured by the HPLC method. Among the red wines tested, "Medvedja krv" and "Vranac" contained the highest total phenolic content with $3080 \pm 101$ and $2850 \pm 93 \mathrm{mg} / \mathrm{l}$, respectively. All analyzed red wines exerted remarkable antioxidant activities. In all cases, malvidin-3-glucoside was a predominant anthocyanin.According to the obtained results, the red wines from Serbia could be a good dietary source of polyphenols.
Keywords: red wines, phenolic, antioxidant activities, spectrophotometric method, HPLC method

\section{Introduction}

Phenolic compounds contribute to many sensory attributes of the wine including color, astringency, structure and mouth feel [1]. The phenolic composition is largely determined by the grape cultivar and oenological practices, and the ranges between 1000 and $5000 \mathrm{mg} / \mathrm{L}$ of total phenols for young red wines [2]. Prior to or during fermentation, grape maceration and the skin contact are important determinants to the levels of phenols, as there are numerous opportunities for the extraction of tannins and flavonoids from the skins and seeds which contribute to astringency. Cold extraction, cap management, fermentation vessels and temperature are also known to significantly affect the phenolic composition [3]. The maturation of the wine in oak barrels allows the agaseous exchange and an influx of atmospheric oxygen which modifies itself and may assemble the phenolic components [2].

Anthocyanins are responsible for most of the red, blue, and purple colours of fruits, vegetables, flowers, and other plant tissues of the products. The amount and composition of anthocyanins in red wine grapes vary greatly in species, cultivar, maturity, season, region, and yield [4].

The anthocyanins extracted from the skins of grapes during crushing, pressing, and fermentation are the major components responsible for the red wine color. It is generally accepted that the color of the red wine changes during maturation and aging, due to interactions between anthocyanins and colorless phenols present in grapes including (+)-catechin, (-)-epicatechin, quercetin, kaemferol, and phenolic acids [4, 5]. The contact with the oak wood of barrels or wood chips during maturation can result in the extraction of the additional phenolics from the wood into the wine. In addition to their direct role in the color, anthocyanins also contribute to the taste and chemical characteristics of the wine because of their interactions with other molecules such as colorless phenols, polysaccharides, metals, and anthocyanins themselves $[5,6]$. The color components of the wine are important parameters that contribute to sensory characteristics (color and astringency) and the antioxidant properties of the wine [7]. With aging, the monomeric anthocyanins are thought to be gradually incorporated into polymeric pigments and this confers color stability of the wine. In relation to their antioxidant characteristics $[7,8,9]$, the objective measurement of the components of the wine color is the essential part of the modern concept of winemaking- "Red Wine Color Management".

So, the aim of this study was to determine some basic chemical characteristics of the tested wines and, for the first time, to investigate the anthocyanin profile and the antioxidant capacity of several red wines produced in Serbia and Macedonia.

\section{Experimental part}

\section{Wine samples}

Representative, high-quality, Serbian red wines were tested (Table1). All the wines examined were produced according to standard procedures and with a defined

\footnotetext{
*Author address: Milan N. Mitić, Faculty of Sciences and Mathematics, Department of Chemistry, University of Niš, 33 Višegradska Street, 18000 Niš, Serbia E-mail: milanmitic83@yahoo.com

The manuscript received: April, 14, 2014.

Paper accepted: Jun, 12, 2014.
} 
varietal composition. All samples were stored at $10^{\circ} \mathrm{C}$ in the dark and analyzed shortly after opening. All the wines analyzed are frequently consumed in Serbia and Macedonia.

Table 1. Originand varietal composition of the wines tested

\begin{tabular}{llll}
\hline Wine & Appelation & Cultivar(s) & Location \\
W1 & Ždrepčeva krv & Vranac, Merlot, C. Souvignon & Subotica-Serbia \\
W2 & Međaš beli & Merlot, Game, Burgundac & Aleksandrovac-Serbia \\
W3 & Medveđa krv & Prokupac, Vranac & Kruševac-Serbia \\
W4 & Kratošja & Kratošija & Aleksandrovac-Serbia \\
W5 & Merlot & Merlot & Subotica-Serbia \\
W6 & Game & Game & Kruševac-Serbia \\
W7 & Cabernet Souvignon & Cabernet Souvignon & Kruševac-Serbia \\
W8 & Cabernet Souvignon & Cabernet Souvignon & Tikveš-Macedonia \\
W9 & Ždrebac & Vranac & Subotica-Serbia \\
W10 & Vranac & Vranac & Aleksandrovac-Serbia \\
W11 & Vranac & Vranac & Kruševac-Serbia \\
W12 & Vranac & Vranac & Štip-Macedonia \\
W13 & Vranac & Vranac & Ohrid-Macedonia \\
W14 & Vranac & Vranac & Ovčepolsko-Macedonia \\
W15 & Vranac & Vranac & Skoplje-Macedonia \\
\hline
\end{tabular}

\section{Chemicals}

The 6-hydroxy-2,5,7,8-tetramethylchroman-2-carboxylic acid (Trolox), 2,2-diphenyl-1-picrylhydrazyl (DPPH), Folin-Ciocalteu's phenol reagent,gallic acid and (+)-catechin were from Sigma-Aldrich (Steineheim, Germany). Sodium hydroxide, sodium nitrite, sodium carbonate, aluminum chloride heksahidrate, methanol,acetonitrile (HPLC grade) and formic acid (HPLC grade) were purchased from Merck® (KGaA, Darmstadt, Germany). All standards for HPLC determination were purchased from Sigma-Aldrich (Steineheim, Germany) and were of HPLC quality.

\section{Instruments}

An Agilent 8453 UV/Vis spectrophotometer with an optical cuvette of $1 \mathrm{~cm}$ was used for all antioxidant capacity measurements. In order to determinetheindividualanthocyanincompound, Agilent-1200 seriesHPLC withthe UV-Vis photodiode array detector(DAD) wasused.

\section{Determination of the total phenolic content (TP)}

The total phenolic content of the wines was determined spectrophotometrically according to theFolin-Ciocalteu method [10]. The samples of the wine were diluted with methanol (1:100). Then, an aliquot $(1 \mathrm{ml})$ of the red diluted wine and $0.5 \mathrm{ml}$ of Folin-Ciocalteu reagent were mixed into a $25 \mathrm{ml}$ calibrated flask. Exactly $1 \mathrm{~min}$. later, $5 \mathrm{ml}$ of sodium carbonate (5\% v/v) was added, and the volume was made to $25 \mathrm{ml}$ with deionized water.The absorbance was measured at $765 \mathrm{~nm}$ after the incubation for $1 \mathrm{~h}$ in the dark, at room temperature. The total polyphenolic concentration was calculated from a calibration curve (1-50 mg/L) using gallic acid as a standard,and the content was expressed as mg gallic acid equivalent (GAE)/L of the wine. All samples were analyzed in triplicate.
Determination of total flavonoid content (TF)

The measurement of the total flavonoid content in the investigated wines was determined spectrometically [11] by using the method based on the formation of the complex flavonoid-aluminium. $0.5 \mathrm{ml}$ (diluted 1:50 with methanol) ofthe wine was placed in a $10 \mathrm{ml}$ volumetric flask, and $5 \mathrm{ml}$ of distilled water and $0.3 \mathrm{ml}$ of $5 \% \mathrm{NaNO}_{2}$ was added and mixed. $5 \mathrm{~min}$. later, $0.6 \mathrm{ml}$ of $10 \% \mathrm{AlCl}_{3} \cdot 6 \mathrm{H}_{2} \mathrm{O}$ was added. Two milliliters of $1 \mathrm{~mol} / \mathrm{L} \mathrm{NaOH}$ were added $5 \mathrm{~min}$ later, and then the volume was made with distilled water up to $10 \mathrm{ml}$. The solution was mixed well and the absorbance was immediately measured at $510 \mathrm{~nm}$. The flavonoid contents were calculated by using a standard calibration curve, prepared from $(+)$-catechin $(R 2=0.992)$.

Determination of total antioxidant activity (TAA)

The DPPH radical scavenging method [12] was based on the reduction of DPPH radical in the presence of a hydrogen-donating antioxidant, in the methanol solution. DPPH radical solution showed an absorption band at $515 \mathrm{~nm}$ and was of the intensively violet color. The absorption and color intensity decreased when DPPH was reduced by an antioxidant compound. The remaining DPPH radical corresponded inversely to the radical scavenging activity of the antioxidant. Each wine was diluted 1:10 with methanol immediately before the analysis. In the test tubes, $0.2 \mathrm{ml}$ of the samples was added to $4.8 \mathrm{ml}$ of the DPPH solution $(5.2 \times 10-6 \mathrm{~mol} / \mathrm{L}$ in methanol) and the mixture was well mixed. The absorbance at $515 \mathrm{~nm}$ was measured at 30 min against a blank ( $0.2 \mathrm{ml}$ methanol and $4.8 \mathrm{ml}$ DPPH solution in methanol). All determinations were performed in triplicate.

The radical scavenging capacity (RSC), expressed in percentage, was calculated by the following equation [13]:

RSC $(\%)=100 \frac{A(\text { Blank })-A(\text { sample })}{A(\text { Blank })}$

The chart of the remaining DPPH concentration against the concentration of Trolox in standard samples was used to calculate the total antioxidant activity (TAA) of the wines. The antioxidant potency (AP) of total phenols for each cultivar wine was calculated as the ratio of TAA to total phenols (TP) [14]:

$A P=\frac{T A A}{T P \cdot 100}$

Determination of monomeric anthocyanins

The total monomeric anthocyanin content in the wine samples was determined by using the $\mathrm{pH}$-differential method described by Guisti and Wrolstad (2003) [15]. Anthocyanins have the maximum absorbance at the wavelength of $520 \mathrm{~nm}$ and at the $\mathrm{pH}$ of 1.0. The coloredoxonium form predominates at $\mathrm{pH} 1.0$ and the colorlesshemiketal forms at $\mathrm{pH}$ 4.5. The $\mathrm{pH}$-differential method is based on this reaction and permits an accurate and rapid measurement of the total monomeric anthocyanins.

The result, considered as the monomeric anthocyanin 
pigment, was calculated as mg of malvidin-3-glucoside, using a molar absorptivity $(\varepsilon)$ of $28.000 \mathrm{~L} / \mathrm{mol} \cdot \mathrm{cm}$ and a molecular weight of 493 . The data presented are the averages of the three measurements.

Determination of the indices for the anthocyanin pigment degradation and polymeric color

Indices for the anthocyanin degradation in the wine can be derived by using the $\mathrm{pH}$-differential method described by Guisti and Wrolstad (2003) [15].The absorbance at $420 \mathrm{~nm}$ of the bisulfite treated sample served as an index for browning. The color density is defined as the sum of the absorbances at the maximum absorbance and at $420 \mathrm{~nm}$. The ratio between the polymerization color and the color density was used to determine the percentage of the color. The data presented are the averages of the three measurements.

HPLC analysis of the individual anthocyanin compounds

For the determination of individual anthocyanin compounds, we used HPLC Agilent-1200 series with UVVis photodiode array (DAD). The column was thermostated at $30{ }^{\circ} \mathrm{C}$. After injecting $5 \mu \mathrm{L}$ of the sample, the separation was performed in an Agilent-Eclipse XDB C-18 4.6×150 mm column. Peaks were identified by the comparison of retention times and UV spectra with commercial standards: delphinidin 3-glucoside, cyanidin3glucoside, petunidin 3-glucoside, peonidin 3-glucoside and malvidin 3-glucoside, as well as with those found in literature [16]. The concentration of anthocyanins is expressed as $\mathrm{mg} / \mathrm{L}$ malvidin 3-glucoside. The range of the linear calibration curve for malvidin 3-glucoside was from 0.5 to $50.0 \mathrm{mg} / \mathrm{L}\left(R^{2}=0.991\right)$. Two solvents were used for the gradient elution: $\mathrm{A}-\left(\mathrm{H}_{2} \mathrm{O}+5 \% \mathrm{HCOOH}\right)$ and $\mathrm{B}-\left(80 \% \mathrm{ACN}+5 \% \mathrm{HCOOH}+\mathrm{H}_{2} \mathrm{O}\right)$. The elution program used was the following: from 0 to $28 \mathrm{~min}, 0.0 \% \mathrm{~B}$, from 28 to $35 \mathrm{~min}, 25 \% \mathrm{~B}$, from 35 to $40 \mathrm{~min}, 50 \% \mathrm{~B}$, from 40 to $45 \mathrm{~min}, 80 \% \mathrm{~B}$, and finally for the last $10 \mathrm{~min}$ again $0 \% \mathrm{~B}$.

\section{Statistical analysis}

All samples were reported and analyzed in triplicate. The statistical analysis was done with the one-way analysis of variance. The Pearson correlation coefficient (R) and $p$-value were used to show the correlations and their significance. Probability values of $p<0.05$ and $p<0.01$ were considered statistically significant and extremely significant, respectively [17].

\section{Results and discussions}

Total phenolic and flavonoid compound content

The results of the determination of the total phenolic content in red wines by the Fiolin-Ciocalteu method are presented in Table 2. The total phenolic content varies from 2381 to $3080 \mathrm{mg} / \mathrm{L}$. According to these researchers, the most interesting sort with high levels of total phenols is "Medvedja krv". The red wine "Medvedja krv"comes from ancient grape sorts "Vranac" and "Prokupac". "Vranac" originated in the Balcans and is the most common type in Serbia and Macedonia. This highly estimated sort yields intensely coloured, strong, full-bodied wines. The skin of "Prokupac" is of a dark blue colour, with characteristic dots. Unlike wines produced from some other red-berried varieties, the wines produced from Vranac and Prokupac are smooth and have a noticable varietal flavour. These indigenous varieties are compared to the international wine varieties Cabernet Souvignon, Merlot and Game.

Table 2. Total phenol (TP) and total flavonoid (TF) contents

\begin{tabular}{cccc}
\hline Wine & $\begin{array}{c}\mathrm{TP}^{\mathrm{a}} \\
(\mathrm{mg} \mathrm{GAE} / \mathrm{L})\end{array}$ & $\begin{array}{c}\mathrm{TF}^{\mathrm{b}} \\
(\mathrm{mg} \mathrm{CE} / \mathrm{L})\end{array}$ & $\mathrm{TF} / \mathrm{TP}$ \\
\hline W1 & $2321 \pm 81^{\mathrm{c}} \mathrm{a}$ & $1578.9 \pm 50.3^{\mathrm{c}} \mathrm{a}$ & 0.68 \\
W2 & $2738 \pm 86 \mathrm{bc}$ & $1802.3 \pm 68 \mathrm{bc}$ & 0.66 \\
W3 & $3080 \pm 101 \mathrm{bc}$ & $1950.2 \pm 68.4 \mathrm{bc}$ & 0.63 \\
W4 & $2800 \pm 95 \mathrm{bc}$ & $1850.2 \pm 61.6 \mathrm{bc}$ & 0.66 \\
W5 & $2620 \pm 95 \mathrm{ab}$ & $1762.3 \pm 59.9 \mathrm{abc}$ & 0.67 \\
W6 & $2665 \pm 87 \mathrm{ab}$ & $1820.1 \pm 62.7 \mathrm{bc}$ & 0.68 \\
W7 & $2429 \pm 82 \mathrm{a}$ & $1682.3 \pm 57.2 \mathrm{ab}$ & 0.69 \\
W8 & $2860 \pm 105 \mathrm{bc}$ & $1998.4 \pm 69.9 \mathrm{bc}$ & 0.7 \\
W9 & $2377 \pm 78 \mathrm{a}$ & $1580.2 \pm 50.5 \mathrm{a}$ & 0.66 \\
W10 & $2561 \pm 84 \mathrm{ab}$ & $1772.3 \pm 67.3 \mathrm{abc}$ & 0.69 \\
W11 & $2668 \pm 98 \mathrm{ab}$ & $1770.5 \pm 60.2 \mathrm{abc}$ & 0.66 \\
W12 & $2525 \pm 84 \mathrm{ab}$ & $1720.2 \pm 59.9 \mathrm{ab}$ & 0.68 \\
W13 & $2850 \pm 93 \mathrm{bc}$ & $1955.3 \pm 66.5 \mathrm{c}$ & 0.69 \\
W14 & $2379 \pm 76 \mathrm{a}$ & $1735.8 \pm 57.3 \mathrm{abc}$ & 0.73 \\
W15 & $2850 \pm 99 \mathrm{bc}$ & $1910.8 \pm 63.8 \mathrm{c}$ & 0.66 \\
\hline
\end{tabular}

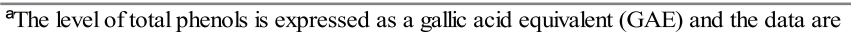
reported as mean \pm standard deviation $(n=3)$

${ }^{\mathrm{b}}$ The level of total flavonoids is expressed as a catechin equivalent (CE) and the data are reported as mean \pm standard deviation $(\mathrm{n}=3)$

${ }^{\mathrm{c}}$ Values in the same columns sharing different letters expressed as significantly different $(\mathrm{p}<0.05)$

Significant differences were found in the total phenolic contents in comparisons among Vranac (OhridMacedonia; Skoplje-Macedonia), Vranac (OvčepolskoMacedonia) and Ždrebac(Subotica-Serbia) $(p<0.05$ ); However, significant differences in total phenolic contents were not found between Vranac (AleksandrovacSerbia) and Vranac (Štip-Macedonia) and between Ždrebac (Subotica-Serbia) and Vranac (AleksandrovacSerbia) $(p<0.05)$. The total phenolic content of Cabernet Souvignon (W7) and Game (W6), Merlot (W5) and Kratošija (W4) were similar ( $p>0.05)$ but lower $(p<0.05)$ than that of Cabernet Souvignon (W8), Vranac (W13) and Vranac (W15). It is well known that both genetic and agronomic or environmental factors play important roles in the phenolic composition and thus the nutritional quality of the crops.

While comparing these results with literature, similar values were reported for red wines which grow in Croatia (2193$3183 \mathrm{mg} \mathrm{GAE} / \mathrm{L}$, [18]) and Greece (1217-3772 mg GAE/L, [19]). Italian red wines have a higher value (3888-5860 mg GAE/L [20]), but Spanish red wines (1262-2389 mg GAE/L, [8]), Turkish red wines (1130-2410 mg GAE/L, [21]) and South African red wines (2016-2412 mg GAE/L, [13]) have similar values of the total phenolic content. 
Furthermore, the results obtained from the evaluation of the total flavonoid content also indicate great variations (Table 2). The Cabernet Souvignon (TikvešMacedonia) showed the highest flavonoid content $(1998.4 \pm 69.9 \mathrm{mg}$ of the catechin equivalent/L of red wines), followed by Vranac (W13), Medveđa krv, Vranac (W15), Kratošia, Game, Medjaš blank, Vranac (W10), Vranac (W11), Merlot, Vranac (W14), Vranac (W12), Cabernet Souvignon (W7), Ždrebac and Ždrepčeva krv. The flavonoid contents of Vranac (Ohrid-Macedonia) and Vranac (Skoplje-Macedonia) were significantly different from Ždrebac(Subotica-Serbia) $(p<0.05)$. Hovewer, any significant differences in the flavonoid content were not found in comparisons among Vranac (Ohrid-Macedonia), Vranac (Skoplje-Macedonia), Vranac (OvčepolskoMacedonia), Vranac (Kruševac-Serbia) and Vranac (Aleksandrovac-Serbia) $(p<0.05)$.

The average percentage of flavonoids in total phenols was $67.6 \%$. The high flavonoid content in the red vines contributes to its increased antioxidant potential in comparison to the white wine [18].

Free radical scavenging capacity (RSC)

The radical-scavenging capacity was evaluated by measuring the scavenging activity of the examined wine samples on 2,2-diphenyl-1-picrylhydrazyl (DPPH-) radicals. All antioxidant results are summarized in Table 3. The percentage RSC for red wines was 74.8-87.9 \%. The percentage for Croatian red wines [20] (after dilution $1: 10, v / v$ ) was $54.6-82.2 \%$ and for Greek wines (after dilution $1: 10, v / v)$ it was $42.2-60.0 \%$ [21].

Table 3. Radical scavenging capacity (RSC), total antioxidant activity (TAA) and antioxidant potency (AP) in different red wines

\begin{tabular}{cccc}
\hline Wine & $\begin{array}{c}\text { RSC } \\
(\%)\end{array}$ & $\begin{array}{c}\text { TAA }^{\mathrm{a}} \\
(\mathrm{mM} \text { Trolox })\end{array}$ & AP $^{\mathrm{b}}$ \\
\hline W1 & $77.4 \pm 0.9$ & $13.5 \pm 0.36^{\mathrm{c}} \mathrm{a}$ & $5.82 \pm 0.72$ \\
W2 & $83.7 \pm 0.8$ & $14.6 \pm 0.48 \mathrm{a}$ & $5.33 \pm 0.63$ \\
W3 & $85.9 \pm 0.8$ & $15.0 \pm 0.48 \mathrm{a}$ & $4.87 \pm 0.52$ \\
W4 & $83.7 \pm 0.3$ & $14.6 \pm 0.45 \mathrm{a}$ & $5.21 \pm 0.58$ \\
W5 & $81.8 \pm 0.8$ & $14.3 \pm 0.47 \mathrm{a}$ & $5.46 \pm 0.67$ \\
W6 & $80.3 \pm 0.7$ & $14.0 \pm 0.43 \mathrm{a}$ & $5.25 \pm 0.43$ \\
W7 & $78.5 \pm 0.3$ & $13.7 \pm 0.46 \mathrm{a}$ & $5.64 \pm 0.28$ \\
W8 & $87.9 \pm 0.2$ & $14.3 \pm 0.46 \mathrm{a}$ & $5.00 \pm 0.62$ \\
W9 & $77.8 \pm 0.2$ & $13.1 \pm 0.43 \mathrm{a}$ & $5.51 \pm 0.82$ \\
W10 & $79.5 \pm 0.8$ & $13.8 \pm 0.52 \mathrm{a}$ & $5.41 \pm 0.75$ \\
W11 & $84.6 \pm 0.5$ & $14.7 \pm 0.48 \mathrm{a}$ & $5.53 \pm 0.67$ \\
W12 & $82.6 \pm 0.4$ & $14.4 \pm 0.46 \mathrm{a}$ & $5.71 \pm 0.55$ \\
W13 & $83.8 \pm 0.3$ & $14.6 \pm 0.38 \mathrm{a}$ & $5.13 \pm 0.57$ \\
W14 & $79.5 \pm 0.2$ & $13.8 \pm 0.39 \mathrm{a}$ & $5.80 \pm 0.39$ \\
W15 & $86.3 \pm 0.7$ & $15.0 \pm 0.40 \mathrm{a}$ & $5.28 \pm 0.48$ \\
\hline
\end{tabular}

${ }^{\mathrm{a}}$ The level of total antioxidant activity is expressed as a Trolox equivalent and the data are reported as mean \pm standard deviation $(\mathrm{n}=3)$

${ }^{\mathrm{b}} \mathrm{AP}($ antioxidant potency $)=\mathrm{TAA}(\mathrm{mM}$ Trolox $) \times 1000 /$ total phenols (mg gallic acid equiv/L)

${ }^{c}$ Values in the same columns sharing different letters expressed as significantly different $(\mathrm{p}<0.05)$
The total antioxidant activity (TAA) for wine samples was of the same order of magnitude using the DPPH scavenging assay when expressed in terms of Trolox. Any significant differences in TAA were not found between the analyzed red wines $(p<0.05)$. The TAA values of the red wines (13.1-15.0 mMTrolox) analyzed in this study were in the range of the wines from other wine producing countries such as France (9.6-29.9 mM Trolox, [22]), Italy (6.1-19.8 mM Trolox, [23]), Canada (7.5-28.6 $\mathrm{mM}$ Trolox, [24]) and Spain (14 mM Trolox, [25]).

\section{Spectrophotometric analysis of anthocyanins}

The monomeric anthocyanin content of the analyzed red wines is presented in Table 4. The mean monomeric anthocyanin content of the analyzed red wines was $63.3 \mathrm{mg} / \mathrm{L}$. The highest concentration of the anthocyanin pi-gment was found in the young wine (Cabernet Souvignon, 2010). The monomeric anthocyanin content of Cabernet Souvignon (W8) was significantly different from all others $(p<0.05)$. However, any significant differences in the monomeric anthocyanin content were not observed among Vranac (Štip-Macedonia), Vranac(OhridMacedonia) and Vranac (Skoplje-Macedonia) or among Ždrebac (Subotica-Serbia), Vranac (Aleksandrovac-Serbia) and Vranac (Kruševac-Serbia) $(p<0.05)$.

Table 4. Monomeric anthocyanins, percent polymeric color in different red wines determined by the spectrophotometric method

\begin{tabular}{ccc}
\hline Wine & $\begin{array}{c}\text { Monomeric } \\
\text { anthocyanins }^{\mathrm{a}} \\
(\mathrm{mg} / \mathrm{L})\end{array}$ & $\begin{array}{c}\text { Percent polymeric } \\
\text { color }(\%)^{\mathrm{b}}\end{array}$ \\
\hline $\mathrm{W} 1$ & $62.2 \pm 5.5^{\mathrm{c}} \mathrm{bc}$ & $70.4 \pm 0.9$ \\
W2 & $77.5 \pm 6.2 \mathrm{c}$ & $65.2 \pm 0.7$ \\
W3 & $46.6 \pm 3.9 \mathrm{ab}$ & $76.9 \pm 1.2$ \\
W4 & $43.1 \pm 2.9 \mathrm{ab}$ & $77.1 \pm 1.0$ \\
W5 & $38.8 \pm 3.2 \mathrm{ab}$ & $79.9 \pm 1.1$ \\
W6 & $63.5 \pm 5.0 \mathrm{bc}$ & $70.1 \pm 0.6$ \\
W7 & $30.5 \pm 2.4 \mathrm{a}$ & $85.5 \pm 0.8$ \\
W8 & $165.5 \pm 9.9 \mathrm{c}$ & $36.5 \pm 0.9$ \\
W9 & $54.1 \pm 4.5 \mathrm{~b}$ & $72.0 \pm 1.2$ \\
W10 & $48.5 \pm 4.2 \mathrm{ab}$ & $73.2 \pm 1.1$ \\
$\mathrm{~W} 11$ & $55.7 \pm 4.2 \mathrm{bc}$ & $72.9 \pm 0.7$ \\
$\mathrm{~W} 12$ & $63.8 \pm 5.3 \mathrm{bc}$ & $70.0 \pm 0.6$ \\
$\mathrm{~W} 13$ & $79.3 \pm 5.4 \mathrm{c}$ & $66.2 \pm 0.5$ \\
$\mathrm{~W} 14$ & $50.2 \pm 4.0 \mathrm{ab}$ & $80.0 \pm 1.1$ \\
$\mathrm{~W} 15$ & $70.3 \pm 4.8 \mathrm{bc}$ & $70.1 \pm 0.9$ \\
\hline
\end{tabular}

${ }^{a}$ The level of monomeric anthocyanins is expressed as a malvidin-3-glucoside equivalent and the data are reported as mean \pm standard deviation $(n=3)$

$\mathrm{b}_{\%}$ polymeric color $=($ polymeric color $/$ color density $) \times 100$

${ }^{\mathrm{c}}$ Values in the same columns sharing different letters expressed as significantly different $(\mathrm{p}<0.05)$

The polymeric anthocyanin pigments are stable compounds responsible for chromatic properties of the wine. These compounds are formed during the wine making process and in the time of aging through reactions which take place between free anthocyanins and tannin. During winemaking and aging, anthocyanins are thought 
to react with tannins to give rise to polymeric pigments, polymeric color was $36.5-85.5 \%$ depending on the age the stable color compounds in the wine. In our case, the of the wine and the variety of the grapes used.

Table 5. Individual anthocyanins ( $\mathrm{mg} / \mathrm{L})$ of red wines determined by HPLC

\begin{tabular}{lccc}
\hline \multicolumn{1}{c}{ Wine } & Merlot, W5 & Vranac, W11 & Vranac, W15 \\
\hline Delphinidin-3-glucoside & $1.22 \pm 0.02$ & $4.75 \pm 0.20$ & $3.85 \pm 0.09$ \\
Cyanidin-3-glucoside & $0.13 \pm 0.01$ & $0.43 \pm 0.05$ & $1.27 \pm 0.05$ \\
Petunidin-3-glucoside & $1.52 \pm 0.04$ & $4.82 \pm 0.18$ & $5.72 \pm 0.17$ \\
Peonidin-3-glucoside & $0.54 \pm 0.02$ & $3.84 \pm 0.11$ & $6.75 \pm 0.21$ \\
Malvidin-3-glucoside & $15.47 \pm 0.15$ & $26.52 \pm 0.35$ & $33.29 \pm 0.56$ \\
Delphinidin-3-glucoside acetate & $0.76 \pm 0.09$ & $0.26 \pm 0.03$ & $0.28 \pm 0.05$ \\
Cyanidin-3-glucoside acetate & $1.09 \pm 0.08$ & $0.14 \pm 0.02$ & $0.38 \pm 0.06$ \\
Petunidin-3-glucoside acetate & $1.26 \pm 0.03$ & $0.28 \pm 0.02$ & $0.29 \pm 0.03$ \\
Peonidin-3-glucoside acetate & nd & $0.78 \pm 0.07$ & $1.01 \pm 0.18$ \\
Malvidin-3-glucoside acetate & $7.47 \pm 0.10$ & $2.34 \pm 0.10$ & $4.67 \pm 0.12$ \\
Delphinidin-3-glucoside coumarate & $0.62 \pm 0.05$ & nd & $0.46 \pm 0.09$ \\
Cyanidin-3-glucoside coumarate & $0.26 \pm 0.01$ & $0.10 \pm 0.02$ & $0.28 \pm 0.07$ \\
Petunidin-3-glucoside coumarate & $0.14 \pm 0.02$ & $0.09 \pm 0.03$ & $0.17 \pm 0.06$ \\
Peonidin-3-glucoside coumarate & $0.16 \pm 0.02$ & $0.64 \pm 0.05$ & $0.84 \pm 0.12$ \\
Malvidin-3-glucoside coumarate & $0.87 \pm 0.02$ & $2.68 \pm 0.06$ & $3.11 \pm 0.18$ \\
Malvidin-3-glucoside coumarate-cis & nd & $0.36 \pm 0.03$ & $0.43 \pm 0.08$ \\
Vitisin A & $1.62 \pm 0.08$ & $1.23 \pm 0.10$ & $1.36 \pm 0.06$ \\
Malvidin-3-glucoside-vinylphenol & nd & $0.07 \pm 0.10$ & $0.21 \pm 0.03$ \\
Total ${ }^{\mathrm{a}}$ & 33.13 & 49.65 & 64.23
\end{tabular}

${ }^{\mathrm{a}}$ The value is expressed as malvidin-3-glucoside equivalent and the data are presented as mean \pm standard deviation $(\mathrm{n}=3)$

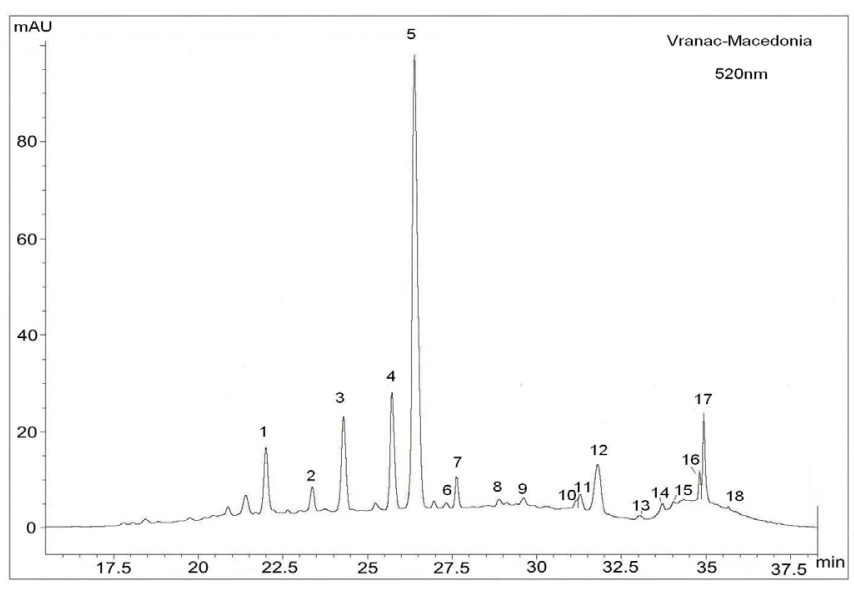

Figure 1. Chromatogram of the red wine. Peaks identification: Delphinidin-3-glucoside (1), Cyanidin-3-glucoside (2), Petunidin-3-glucoside (3), Peonidin-3-glucoside (4), Malvidin3-glucoside (5), Delphinidin-3-glucoside acetate (6), Vitisin A (7), Cyanidin-3-glucoside acetate (8), Petunidin-3-glucoside acetate (9), Delphinidin-3-glucoside coumarate (10), Peonidin3-glucoside acetate (11), Malvidin-3-glucoside acetate (12), Cyanidin-3-glucoside coumarate (13), Malvidin-3-glucoside coumarate-cis (14), Petunidin-3-glucoside coumarate (15), Peonidin-3-glucoside coumarate (16), Malvidin-3-glucoside coumarate (17), Malvidin-3-glucoside-vinylphenol (18). Chromatogram was recorded at $520 \mathrm{~nm}$. Chromatographic separations were obtained on a Agilent-Eclipse XDB C-18 column (5.0 $\mu \mathrm{m}$ pa-rticle size, $4.6 \times 150 \mathrm{~mm}$ ) using a binary gradient (mobile phase $\mathrm{A}, 5 \% \mathrm{HCOOH}$ in water; mobile phase $\mathrm{B}, 80 \% \mathrm{ACN}$ and $5 \% \mathrm{HCOOH}$ in water). The operating conditions were: flow rate $0.8 \mathrm{ml} / \mathrm{min}$; column temperature $30^{\circ} \mathrm{C}$.
HPLC analysis of individual anthocyanins in red wines Vranac and Merlot

In Table 5 the results of individual anthocyanin compounds in the red wine Vranac (Serbia and Macedonia) and Merlot (Serbia) are reported. Fig. 1 shows the chromatogram of the wine samples monitored at 520 $\mathrm{nm}$. In all cases, the predominant anthocyanin was malvidin-3-glucoside (mean value $25.09 \mathrm{mg} / \mathrm{L}$ ), accounting for approximately $45.7 \%$ of all pigments in contrast. Cyaniding-3-glucoside had the lowest mean content $(0.61$ $\mathrm{mg} / \mathrm{L}$ ), with its percentage to the overall concentration being only $1.1 \%$. Malvidin-3-glucoside was the main anthocyanin of all varieties. Therefore, its derivatives were also the main anthocyanins in the acetylated and coumaroylated forms, and the anthocyanins in acetylated forms were significantly higher for Merlot than for Vranac

\section{Correlations}

In this research, red wine varieties showed a high TP and TF content and high TAA. A significant correlation between TAA and TP $\left(R^{2}=0.85\right)$ (Fig. 2) and TAA and TF content $\left(R^{2}=0.77\right)$ (Fig.3) was found. Further, a good correlation $\left(R^{2}=0.16\right)$ between TAA and MA content was not found (Fig. 4). This suggests that anthocyanins may not be the most powerful radical scavengers that occur in grape berry skins. Recently, many authors $[26,27]$ found a linear correlation between the phenolic content, antioxidant activity and the level of anthocyanins. On the other hand, other researchers $[19,27,28]$ determined that the correlation of total phenols to antiradical or antioxidant activity was even higher but poor with the total anthocya- 


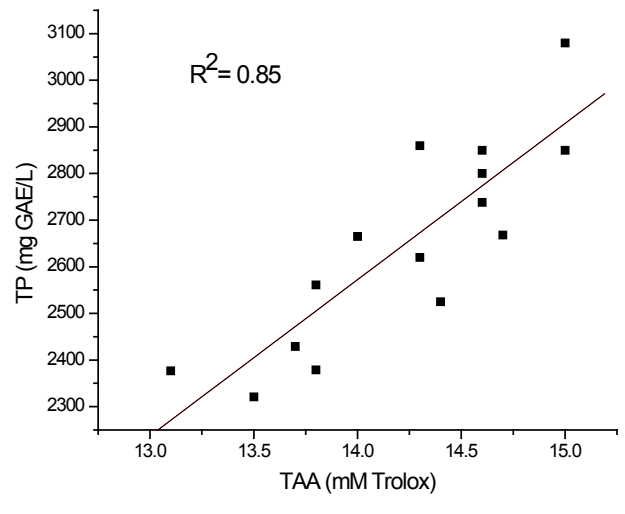

Figure 2. Correlation between the total phenolics and total antioxidant activity

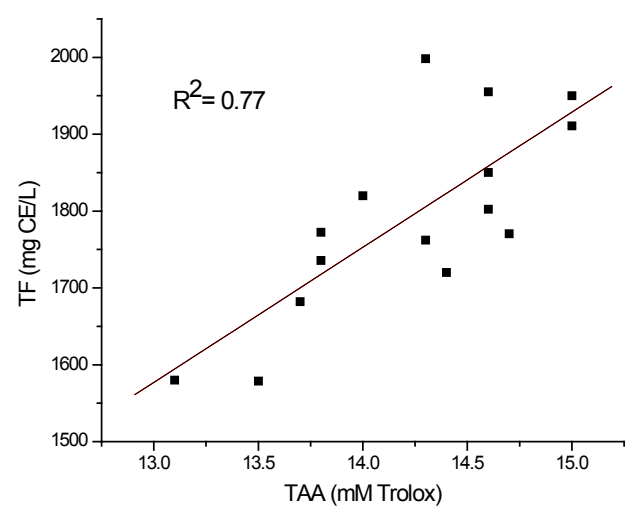

Figure 3. Correlation between the total flavonoids and total antioxidant activity

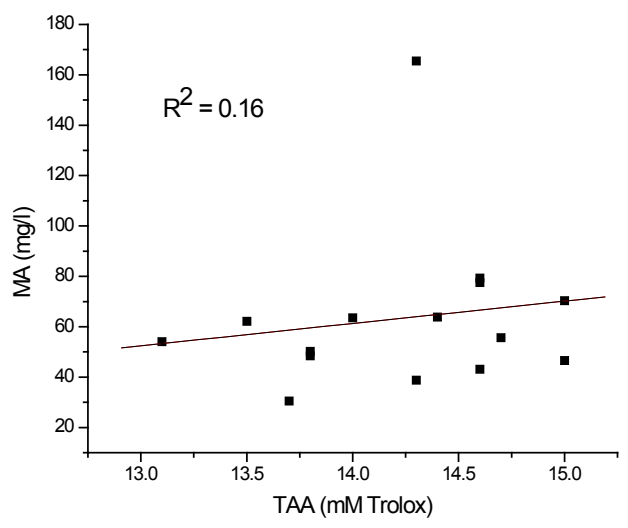

Figure 4. Correlation between monomeric anthocyanins and the total antioxidant activity

\section{Conclusion}

This study showed that, although all the analyzed red wines contained the phenolic compounds, flavonoids and anthocyanins and their contents were significantly different among the grape varieties. All red wine varieties represent a potential source of natural antioxidants, but the variety Medvedja krv showed a better performance. Serbian and Macedonian red wines, produced from indigenous varieties Prokupac and Vranac, can be considered to be a rich source of dietary antioxidants. Our results also showeda significant correlation between the TAA with the TP and TF.

\section{Acknowledgements}

This work was supported by the Serbian Ministry of Education and Science Protection (grant number 174007).

\section{References}

[1] J. W.Rankine,.Making Good Wine. Pan MacMillan Australia Pty Ltd., Sydney.(1995)

[2] J. W.Costin, N. W.Barnett, S. W.Lewis, D. J.McGillivery, Monitoring the total phenolic/anthioxidant levels in wine using flow injection analysis with acyclic potassium permanganate chemiluminescence detection,AnalyticaC himlcaActa.,499 (2003) 47-56.

[3] A. S.Meyer, J. L.Donovan, D. A.Pearson, A.Waterhouse, E. N.Frankel, Fruit hydroxycinnamic acids inhabit human low-density lipoprotein oxidation in vitro,Journal of Agricultural and Food Chemistry,46 (1998) 1783-1787.

[4] G.Mazza,Anthocyanins in grapes and grape products. Critical Reviews in Food Science and Nutrition, 35 (1995) 341-371.

[5] H.Liao, Y.Cai, E.Haslam, Polyphenol interactions Anthocyanins: copigmentation and colour changes in red wines. Journal of Science and Food Agriculture,59 (1992) 299-305.

[6] Y.Cai, T. H.Lilleg, E.Haslam, Polyphenol-anthocyanin copigmentation. Journal of the Chemical Society, Perkin Transactions 1, 2 (1990) 247-257.

[7] M.Monagas, B.Hernandez-Ledesma, C.GomezCordoves, B.Bartolome, Commercial dietary ingredients from Vitisvinifera L. leaves and grape skins: Antioxidant and chemical characterization. Journal of Agricultural and Food Chemistry, 54 (2006) 319-327.

[8] S. M.Fernandez-Pachon, D.Villano, M. C.Garcia-Parrilla, A. M.Troncoso, Antioxidant activity of wines and relation with their poliphenolic composition, AnalyticaChimicaActa, 513 (2004) 113-118.

[9] G.P.Versari, A.U. Parpinello, A. Mattioli,Characterisation of Colour Components and Polymeric Pigments of Commercial Red Wines by Using Selected UV-Vis Spectrophotometric Methods, South African Journal of Enology and Viticulture, 28(1) (2007) 6-10.

[10] V. L.Singleton, A.Rossi,Colorimetry of total phenolics with phosphomolybdic-phosphotungstic acid reagents. American Journal of Enology and Viticulture,16 (1965) 144-158.

[11] Z.Jia, T.Tang, J.Wu,The determination of flavonoids 
content in mulberry and scavenging effect on superoxide radicals, FoodChemistry,64 (1999) 555-559.

[12] W. Brand-Williams, M. E.Cuvelier, C.Berset, Use of a free radical method to evaluate antioxidantactivity. Lebensmittel-Wissenschaft\&Technologie, 28 (1995) 2530.

[13] G. C. Yen, P. D. Duh, Scavenging effect of methanolic extracts of peanut hulls on free-radical and active-oxygen species, Journal of Agriculture and Food Chemistry, 42 (1994) 629-632.

[14] T. De Beer, E. Joubert, W. C. A. Golderblom, M. Manley, Antioxidant Activity of South African Red and White Cultivar Wines: Free Radical Scavenging, Journal of Agricultural and Food Chemistry, 51 (2003) 902-909.

[15] M. M.Guisti, R. E.Wrolstad, 2003. Characterization and measurement of anthocyanins by UV-visible spectroscopy. Current protocols in food analytical chemistry. John Wiley \& Sons, New York.

[16] L.Wulf, C.Nagel,High-pressure liquid chromatographic separation of anthocyanins of Vitisvinifera.American Journal of Enology and Viticulture,29 (1978) 42-49.

[17] V.Bewick, L.Cheek, J.Ball, Statistics review 9: One-way analysis of variance, Critical Care, 8(2004) 130-136.

[18] V.Katalinic, M.Milos, D.Modun, I.Music, M.Boban, Antioxidant effectiveness of selected wines in comparison with (+)-catechin, Food Chemistry,86 (2004) 593-600.

[19] A.Arnous, D. P.Makris, A.Kefalas, Effect of Principal Polyphenolic Components in Relation to Antioxidant Characteristics of Aged red Wines. Journal of Agricultural and Food Chemistry,49(2001) 5736-5742.

[20] F.Cimino, V.Sulfaro, D.Trombetta, A.Saija, A.Tomaino,Radical-scavenging capacity of several Italian red wines. Food Chemistry, 103 (2007) 73-81.
[21] R. E.Anli, N.Vural, Antioxidant Phenolic Substance of Turkish Red Wines from Different Wine Region. Molecules, 14 (2009) 289-297.

[22] M.Landrault, P.Poucheret, P.Ravel, F.Gasc, G.Gros, P. L. Teissedre,Antioxidant capacities and phenolics levels of French wines from different varieties and vintages, Journal of Agricultural and Food Chemistry,49 (2001) 3341-3348.

[23] P.Simonetti, P.Pietta, G.Testolin,Polyphenol content and total antioxidant potential of selected Italian wines.Journal of Agricultural and Food Chemistry,45(1997) 1152-1155.

[24] G.Soleas, G.Tomlinson, E. P.Diamandias, D. M.Goldberg, Relative contributions of polyphenolic constituents to the antioxidant status of wines. Development of a predictive model.Journal of Agricultural and Food Chemistry,45 (1997) 3995-4003.

[25] J. V.Verhagen, G. R. M. M.Haenen, A.Bast, Nitric oxide scavenging by wines.Journal of Agricultural and Food Chemistry,44 (1996) 3733-3744.

[26] W.Kalt, C. F.Forney, A.Martin, R.Prior, Antioxidant capacity, vitamin $\mathrm{C}$, phenolics and anthociany after fresh storage of small fruits, Journal of Agricultural and Food Chemistry,47 (1999) 4638-4644.

[27] S. Y.Wang, S.Lin, Antioxidant activity in fruits and leaves of blackberry, raspberry and strawberry varies with cultivar and development stage.Journal of Agricultural and Food Chemistry,48 (2000) 140-146.

[28] S.Kallithraka, A. A. A.Mohdalya, D. P.Makris, P.Kefalas,Determination of major anthocyanin pigments in Hellenic native grape varieties (Vitisvinifera $\mathrm{sp}$.): association with antradical activity. Journal of Food Composition and Analysis, 18 (2005) 375-386

Izvod

\section{FENOLNI SASTAV I ANTIOKSIDATIVNA AKTIVNOST CRVENIH VINA IZ SRBIJE}

Milan N. Mitić, Danijela A. Kostić, Aleksandra N. Pavlović

Prirodno matematički fakultet, Departman za hemiju, Univerziteta u Nišu, Niš, Srbija

Cilj ovog rada je bio da se ispita fenolni sastav i slobodno-radikalska hvatačka aktivnost, koristeći DPPH metodu, odabranih crvenih vina iz Srbije. Vina od crvenih sorti grožđa, različitih berbi, su analizirana u junu 2012. Standardna spektrofotometrijska metoda je korišćena za analizu glavnih grupa jedinjenja u odabranim vinima. Nakon analize je utvđeno da vina "Medveđa krv" i Vranac imaju najveći sadržaj totalnih fenola sa $3080 \pm 101$ i $2850 \pm 93 \mathrm{mg} / \mathrm{l}$, respektivno. Sva vina su pokazala izuzetnu antioksidativnu aktivnost. U svim slučajevima malvidin-3-glukozid je najzastupljeniji antocijanin. Uskladu sa dobijenim rezuItatima, crvena vina iz Srbije mogu da budu dobar izvor polifenola u ishrani.
(ORIGINALNI NAUČNI RAD) UDC 663.21:543.42

Ključne reči: crvena vina, antioksidativna aktivnost, spektrofotometrijska metoda, HPLC metoda. 